Original paper

DOI: $10.2478 /$ agri-2018-0010

\title{
EFFECTIVENESS OF THE APPLICATION OF NITRIFICATION INHIBITORS ON THE CONTENT OF AVAILABLE NITROGEN FORMS IN THE SOIL AFTER WINTER BARLEY CULTIVATION
}

\author{
ZUZANA RYBÁROVÁ*, PAVOL SLAMKA, OTTO LOŽEK, PETER KOVÁČIK
}

Slovak University of Agriculture in Nitra, Slovak Republic

RYBÁROVÁ, Z. - SLAMKA, P. - LOŽEK, O. - KOVÁČIK, P.: Effectiveness of the application of nitrification inhibitors on the content of available nitrogen forms in the soil after winter barley cultivation. Agriculture (Pol'nohospodárstvo), vol. 64, 2018, no. 3, pp. 95-105.

The aim of this study was to examine the effect of split and one-time application of nitrogen-sulphur fertiliser ENSIN (26\% $\mathrm{N}, 13 \% \mathrm{~S}$ ) containing nitrification inhibitors (dicyandiamide and 1,2,4-triazole) on the content of nitrate and ammonium nitrogen in soil. The study was conducted in field small-plot experiment with winter barley on Haplic Luvisol with dominance of clay fraction in experimental station of the Central Testing Institute in Agriculture of Vel'ké Ripňany in the experimental years 2015 to 2017. The dose of nitrogen in all experimental treatments was $140 \mathrm{~kg} / \mathrm{ha}$ and was applied at once during regenerative fertilisation or split in three partial doses. Soil samples from all examined treatments were taken from two soil depths $(0.0-0.3 \mathrm{~m}$ and $0.3-0.6 \mathrm{~m}$, respectively) by probe rod in three week intervals. Achieved results indicate that in the year 2015/2016, one-time application of fertiliser ENSIN containing nitrification inhibitors considerably reduced portion of $\mathrm{N}_{-} \mathrm{NO}_{3}{ }^{-}$from the content of $\mathrm{N}_{\min }$ by 32 relative $\%$ in soil depth of $0.0-0.3 \mathrm{~m}$ and by 36 relative $\%$ in soil depth of $0.3-0.6 \mathrm{~m}$. On the other hand, in the year 2016/2017, split application of fertiliser ENSIN substantially reduced portion of N-NO ${ }_{3}^{-}$from

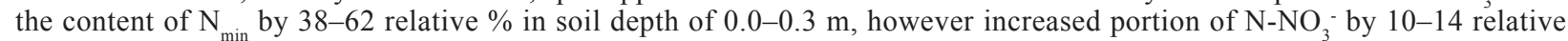
$\%$ in soil depth of $0.3-0.6 \mathrm{~m}$.

Key words: ammonium nitrogen, fertilisation, nitrates, nitrification, nitrification inhibitors

Nitrogen plays an important role on the plant growth and in the formation of yield of the agricultural crops (Fernandez-Escobar et al. 2011). Nitrogen as plant nutrient is usually used in greater quantities than those needed in order to guarantee a high yield in present practices (Sanchez et al. 1995). As a consequence, excessive application of nitrogen through fertiliser may cause environmental degradation due to nitrogen losses (Giménez et al. 2001). Nitrogen losses are caused by nitrate leaching (nitrification), erosion, volatilization, denitrification and fixation in soil organic matter (Marschner 1995). Nitrate leaching from agricultural soils and the contamination of water resources is one of the serious global environmen- tal concerns (Di \& Cameron 2002; Di \& Cameron 2005; Liu et al. 2005; Elbl et al. 2014; Plošek et al. 2017). The high concentration of nitrate nitrogen in groundwater and drinking water can be a health hazard for humans (Knobeloch et al. 2000; Chen et al. 2003) and for livestock (Li et al. 2008).

The aim of developing management strategies and tools for reducing greenhouse gas emissions $\left(\mathrm{NO}_{\mathrm{x}}, \mathrm{N}_{2} \mathrm{O}\right)$ and minimizing nitrogen loss from soils is very important. Adopting mitigation options at large scale by farmers requires simple and efficient tools and methods, as has been the case for nitrification inhibitors (Morales et al. 2015) or urease inhibitors (Musilová et al. 2012).

Nitrification inhibitors are a group of chemical

Ing. Zuzana Rybárová, (*Corresponding author), doc. Ing. Pavol Slamka, PhD., prof. Ing. Otto Ložek, CSc., Prof. Ing. Peter Kováčik, CSc., Department of Agrochemistry and Plant Nutrition, The Faculty of Agrobiology and Food Resources, Slovak University of Agriculture in Nitra, Tr. A. Hlinku 2, 94901 Nitra, Slovak Republic. E-mail: zuzana.panakova89@gmail.com 
compounds that suppress the first step of nitrification by inhibiting Nitrosomonas spp. bacteria that oxidize ammonium nitrogen to nitrite nitrogen, and therefore delay the nitrification process (Huber et al. 1977; Zerulla et al. 2001). Field studies have shown that the efficiency of nitrification inhibitors varies depending greatly on the environmental conditions (Menéndez et al. 2012). Inhibiting process of nitrification through use of nitrification inhibitor can encourage the retention of soil nitrogen as the less mobile ammonium form of nitrogen, which could significantly reduce leaching loss of nitrate nitrogen from the soil. Lower concentration of the soil nitrate nitrogen resulting from the inhibition of nitrification also reduces substrate availability for denitrification and decreases $\mathrm{N}_{2} \mathrm{O}$ emissions (Akiyama et al. 2010).

The exploitation of activity of nitrification inhibitors could become an effective strategy contributing to the development of agronomic systems, benefiting both agriculture and the environment (Zhang et al. 2015).

Including the use for inhibiting nitrification in the soil, the nitrification inhibitor dicyandiamide is used as a basic chemical ingredient for the manufacture of industrial products, in electrical engineering and electronics, for the manufacture of ingredients in the form of food ingredients approved by the USFDA (OECD 2003).

In this study, we hypothesize that the application of nitrification inhibitors dicyandiamide and 1,2,4-triazole in the fertiliser ENSIN will delay microbial oxidation of ammonium nitrogen to nitrate nitrogen in the soil, as a consequence, the concentration of nitrate nitrogen in the soil will be lower.

\section{MATERIAL AND METHODS}

Two-year small-plot experiment with winter barley growing was established on Haplic Luvisol with dominance of clay fraction in experimental station of the Central Testing Institute in Agriculture of Vel'ké Ripňany in the years 2015 to 2017. Current temperatures and precipitations in respective experimental years, as well as long term normal are stated in Table 1 and 2. Soil samples for agrochemical analyses were taken before sowing of winter barley from soil depth of 0.0 to $0.3 \mathrm{~m}$ and 0.3 to $0.6 \mathrm{~m}$, respectively. Agrochemical characteristics of soil samples and their evaluations are stated in Table 3 and 4. In experimental year 2015/2016 sowing of winter barley was carried out at the end of October and the harvest was performed at the end of June. In experimental year 2016/2017 sowing of winter barley was carried out in the first decade of October and the harvest was performed at the end of June.

The scheme of winter barley fertilisation treatments and the doses of nitrogen applied per hectare at respective growth stages are stated in Table 5. The following fertilisers were applied in the field experiment: nitrogen-sulphur fertiliser Ammonium nitrate + Ammonium sulphate DASA 26/13 (26\% N, 13\% S) and fertiliser ENSIN (with the same content of nutrients as fertiliser DASA 26/13) which contains two nitrification inhibitors. Nitrification inhibitors of interest were represented by dicyandiamide (DCD) and 1,2,4-triazole (TZ) which were incorporated directly in the granule of fertiliser ENSIN as its integral part. The advantages of fertiliser ENSIN usage in comparison with fertiliser DASA 26/13 are that ENSIN is applied in one dosage and re-application of the fertiliser is not needed.

The total nitrogen dose of $140 \mathrm{~kg} / \mathrm{ha}$ via nitrogen-sulphur fertilisers DASA 26/13 and ENSIN was applied three times by split application during regenerative fertilisation, production fertilisation and quality fertilisation of winter barley, respectively. Total nitrogen dose of $140 \mathrm{~kg} / \mathrm{ha}$ through fertilisers DASA 26/13 and ENSIN was also applied by only one-time application during regenerative fertilisation of winter barley (Table 5).

Each treatment was replicated four times and each plot was represented by the area of $10 \mathrm{~m}^{2}$ $(8.9 \mathrm{~m} \times 1.125 \mathrm{~m})$. The winter barley vegetation was treated against weeds, diseases and pests by use of standard methods of agrochemical application.

In all treatments, soil samples were taken from soil depth of 0.0 to $0.3 \mathrm{~m}$ and 0.3 to $0.6 \mathrm{~m}$ in the experimental years 2015 to 2017. There were four samplings conducted in an interval of three weeks during winter barley growing season in the experimental years 2015 to 2017 (Table 6).

The contents of ammonium $\left(\mathrm{N}^{-\mathrm{NH}_{4}}{ }^{+}\right)$and nitrate $\left(\mathrm{N}^{-\mathrm{NO}_{3}}{ }^{-}\right)$nitrogen (in $1 \%$ leachate of $\mathrm{K}_{2} \mathrm{SO}_{4}$ ) were determined by the colour method with Nessler test solution and by the colour method with phenol 
2,4-disulphonic acid (Kováčik 1997) in taken soil samples before sowing winter barley and during the vegetation of winter barley, respectively. The content of mineral nitrogen $\left(\mathrm{N}_{\text {min }}\right)$ in soil was calculated as the sum of ammonium $\left(\mathrm{N}-\mathrm{NH}_{4}^{+}\right)$and nitrate $(\mathrm{N}-$ $\mathrm{NO}_{3}^{-}$) nitrogen content.
Nitrate and ammonium nitrogen contents in soil were statistically evaluated by analysis of variance (ANOVA), linear regression analysis using Statgraphics Plus PC software, version 5.1 and the differences between treatments were assessed by $L S D$ test.

$\mathrm{T}$ a

Review of average temperatures in locality of Vel'ké Ripňany

\begin{tabular}{|l|c|c|c|c|c|}
\hline Month & $\begin{array}{c}2015 / 2016 \\
{\left[{ }^{\circ} \mathrm{C}\right]}\end{array}$ & $\begin{array}{c}2016 / 2017 \\
{\left[{ }^{\circ} \mathrm{C}\right]}\end{array}$ & $\begin{array}{c}\text { Long term average } \\
{\left[{ }^{\circ} \mathrm{C}\right] 1981-2010}\end{array}$ & $\begin{array}{c}\text { Difference } \\
2015 / 2016 \\
{\left[{ }^{\circ} \mathrm{C}\right]}\end{array}$ & $\begin{array}{c}\text { Difference } \\
2016 / 2017 \\
{\left[{ }^{\circ} \mathrm{C}\right]}\end{array}$ \\
\hline August & $23.7 \mathrm{EW}$ & $19.7 \mathrm{~N}$ & 19.6 & +4.1 & +0.1 \\
September & $16.5 \mathrm{~N}$ & $17.8 \mathrm{~W}$ & 15.8 & +0.7 & +2.0 \\
October & $10.0 \mathrm{~N}$ & $9.1 \mathrm{~N}$ & 9.9 & +0.1 & -0.8 \\
November & $6.0 \mathrm{~W}$ & $4.8 \mathrm{~N}$ & 4.9 & +1.1 & -0.1 \\
December & $2.6 \mathrm{~W}$ & $-0.4 \mathrm{~N}$ & 0.5 & +2.1 & -5.9 \\
January & $-0.9 \mathrm{~N}$ & $-7.2 \mathrm{VC}$ & -2.2 & +1.3 & +2.7 \\
February & $5.4 \mathrm{EW}$ & $2.4 \mathrm{~W}$ & -0.3 & +2.7 & +3.9 \\
March & $6.2 \mathrm{~N}$ & $8.1 \mathrm{VW}$ & 4.2 & +1.0 & -0.6 \\
April & $11.1 \mathrm{~N}$ & $9.5 \mathrm{~N}$ & 10.1 & +0.9 & +1.2 \\
May & $16.1 \mathrm{~N}$ & $16.4 \mathrm{~N}$ & 15.2 & +2.2 & +3.0 \\
June & $20.6 \mathrm{VW}$ & $21.4 \mathrm{VW}$ & 18.4 & +1.9 & +0.4 \\
\hline October-June & $8.6 \mathrm{VW}$ & $7.1 \mathrm{~N}$ & 6.7 & +2.9 \\
\hline
\end{tabular}

where: VC - very cold; N - normal; W - warm; VW - very warm; EW - extraordinary warm (Kožnárová \& Klabzuba 2002)

$\mathrm{T}$ a

Review of precipitation in locality of Vel'ké Ripňany

\begin{tabular}{|l|c|c|c|c|c|}
\hline \multirow{2}{*}{ Month } & $2015 / 2016$ & $2016 / 2017$ & Long term average & \multicolumn{2}{|c|}{ \% of long term average } \\
\cline { 4 - 6 } & {$[\mathrm{mm}]$} & {$[\mathrm{mm}]$} & {$[\mathrm{mm}] 1981-2010$} & $2015 / 2016$ & $2016 / 2017$ \\
\hline August & $97.1 \mathrm{~W}$ & $45.2 \mathrm{~N}$ & 62.0 & 156.60 & 72.90 \\
September & $29.2 \mathrm{~N}$ & $42.9 \mathrm{~N}$ & 43.0 & 67.90 & 99.80 \\
October & $74.8 \mathrm{~W}$ & $64.5 \mathrm{~W}$ & 37.0 & 202.20 & 174.30 \\
November & $38.9 \mathrm{~N}$ & $47.2 \mathrm{~N}$ & 50.0 & 77.80 & 94.40 \\
December & $15.8 \mathrm{VD}$ & $12.1 \mathrm{VD}$ & 47.0 & 33.60 & 25.70 \\
January & $46.5 \mathrm{~W}$ & $19.2 \mathrm{D}$ & 35.0 & 132.90 & 54.90 \\
February & $96.8 \mathrm{EW}$ & $22.1 \mathrm{~N}$ & 34.0 & 284.70 & 65.00 \\
March & $13.5 \mathrm{D}$ & $23.1 \mathrm{~N}$ & 31.0 & 43.50 & 74.50 \\
April & $28.9 \mathrm{~N}$ & $46.2 \mathrm{~N}$ & 41.0 & 70.50 & 112.70 \\
May & $76.7 \mathrm{~W}$ & $36.3 \mathrm{~N}$ & 55.0 & 139.50 & 66.00 \\
June & $18.0 \mathrm{VD}$ & $19.5 \mathrm{VD}$ & 70.0 & 25.70 & 27.90 \\
\hline October-June & $409.9 \mathrm{~N}$ & $290.2 \mathrm{VD}$ & 400.0 & 102.50 & 72.60 \\
\hline
\end{tabular}

where: VD - very dry; D - dry; N - normal; W - wet; EW - extraordinary wet (Kožnárová \& Klabzuba 2002) 
The portion of nitrate and ammonium nitrogen from mineral nitrogen in the soil was evaluated as the indicator of efficiency of the inhibitory effect of the fertiliser ENSIN. Established portions of $\mathrm{N}-\mathrm{NH}_{4}^{+}$or $\mathrm{N}_{-} \mathrm{NO}_{3}^{-}$were compared to achieved values after application of the fertilisers without nitrification inhibitors.

$$
P=A / B \times 100
$$

where: $P$ - portion of nitrate or ammonium nitrogen from content of mineral nitrogen in soil [\%], $A$ - content of nitrate or ammonium nitrogen in soil $[\mathrm{mg} / \mathrm{kg}]$,

$B$ - content of mineral nitrogen in soil $[\mathrm{mg} / \mathrm{kg}]$.

The contents of available phosphorus and potassium (in leachate of Mehlich III) were determined by colorimetry and by the method of flame photometry, respectively (Mehlich 1984). The contents of available calcium and magnesium (in leachate of Mehlich III) were measured using the atomic absorption spectrophotometer (Mehlich 1984). The content of available sulphur was determined in the solution of ammonium acetate by colorimetry. The exchange soil acidity $\left(\mathrm{pH}_{\mathrm{KCl}}\right)$ was set in the leach- ate of $0.2 \mathrm{M}$ potassium chloride $(\mathrm{KCl})$ (Fiala et al. 1999). The content of oxidable carbon $-\mathrm{C}_{\mathrm{ox}}$ was set by the method of Turina in taken soil samples before sowing winter barley (Ťurin 1966).

\section{RESULTS AND DISCUSSION}

Average air temperature was higher than a long term normal by $0.4^{\circ} \mathrm{C}$ to $1.9^{\circ} \mathrm{C}$ during the winter barley growing season (October - June) in all two experimental years (Table 1). However, substantial differences were found in both amount and distribution of atmospheric precipitation influencing the final concentrations of ammonium $\left(\mathrm{N}^{-\mathrm{NH}_{4}^{+}}\right)$and nitrate $\left(\mathrm{N}^{-\mathrm{NO}_{3}}{ }^{-}\right)$nitrogen in the agricultural soil. In experimental year 2016/2017, deficit of precipitation amounting was pronounced up to $-109.8 \mathrm{~mm}$ during the winter barley growing season in comparison with long term normal (Table 2). The efficiency of nitrification inhibitor to retard nitrate leaching depends on soil properties, such as texture, organic matter, temperature (Zerulla et al. 2001; Ignacio et al. 2003) and moisture, $\mathrm{pH}$, texture, organic carbon and mineral nitrogen (Barth et al. 2001; Shepherd

$\mathrm{T}$ a

Agrochemical characteristic of soil in locality of Vel'ké Ripn̆any $(0.0-0.3 \mathrm{~m})$

\begin{tabular}{|c|c|c|c|c|c|c|c|c|}
\hline \multirow{2}{*}{ Year } & \multicolumn{6}{|c|}{$[\mathrm{mg} / \mathrm{kg}]$} & \multirow{2}{*}{$\begin{array}{l}\mathrm{C}_{\mathrm{ox}} \\
{[\%]}\end{array}$} & \multirow{2}{*}{$\mathrm{pH}_{\mathrm{KCl}}$} \\
\hline & $\mathrm{N}_{\min }$ & $\mathrm{P}$ & $\mathrm{K}$ & $\mathrm{Ca}$ & $\mathrm{Mg}$ & $\mathrm{S}$ & & \\
\hline $2015 / 2016$ & $7.6 \mathrm{~L}$ & $65.0 \mathrm{M}$ & $201.0 \mathrm{M}$ & $2,900 \mathrm{M}$ & $257.0 \mathrm{G}$ & $2.50 \mathrm{VL}$ & $1.06 \mathrm{~L}$ & $6.54 \mathrm{SA}$ \\
\hline $2016 / 2017$ & $14.8 \mathrm{M}$ & $73.0 \mathrm{G}$ & $208.0 \mathrm{M}$ & $1,900 \mathrm{~L}$ & $348.0 \mathrm{H}$ & $1.25 \mathrm{VL}$ & $1.03 \mathrm{~L}$ & $6.84 \mathrm{~N}$ \\
\hline
\end{tabular}

where: VL - very low content; L - low content; M - medium content; G - good content; H - high content; VH - very high content; $\mathrm{pH}_{\mathrm{KCl}}: \mathrm{SA}$ - slightly acidic; $\mathrm{N}$ - neutral

$\mathrm{T}$ a b 1 e 4

Agrochemical characteristic of soil in locality of Vel'ké Ripňany $(0.3-0.6 \mathrm{~m})$

\begin{tabular}{|c|c|c|c|c|c|c|c|c|}
\hline \multirow{2}{*}{ Year } & \multicolumn{6}{|c|}{$[\mathrm{mg} / \mathrm{kg}]$} & \multirow{2}{*}{$\begin{array}{l}\mathrm{C}_{\mathrm{ox}} \\
{[\%]}\end{array}$} & \multirow{2}{*}{$\mathrm{pH}_{\mathrm{KCl}}$} \\
\hline & $\mathrm{N}_{\min }$ & $\mathrm{P}$ & $\mathrm{K}$ & $\mathrm{Ca}$ & $\mathrm{Mg}$ & $\mathrm{S}$ & & \\
\hline $2015 / 2016$ & $6.0 \mathrm{~L}$ & $24.0 \mathrm{~L}$ & $190.0 \mathrm{M}$ & $3,700 \mathrm{G}$ & $350.0 \mathrm{H}$ & $2.5 \mathrm{VL}$ & $0.57 \mathrm{VL}$ & $6.51 \mathrm{SA}$ \\
\hline $2016 / 2017$ & $14.7 \mathrm{M}$ & $30.0 \mathrm{~L}$ & $163.0 \mathrm{M}$ & $2,050 \mathrm{M}$ & $404.0 \mathrm{H}$ & $1.25 \mathrm{VL}$ & $0.81 \mathrm{~L}$ & $6.76 \mathrm{~N}$ \\
\hline
\end{tabular}

where: VL - very low content; L - low content; $\mathrm{M}$ - medium content; $\mathrm{G}$ - good content; $\mathrm{H}$ - high content; VH - very high content; $\mathrm{pH}_{\mathrm{KC}}$ : $\mathrm{SA}$ - slightly acidic; $\mathrm{N}$ - neutral 
et al. 2012). Irigoyen et al. (2003) reported that soil temperature is the most determining factor for the stability of nitrification inhibitors in the soils. The extent to which nitrification inhibitors inhibit $\mathrm{N}_{2} \mathrm{O}$ emissions and nitrate leaching is also dependent on factors such as the application rate, time and method of nitrification inhibitors application (Barth et al. 2008; Verma et al. 2008; O'Connor et al. 2012; Zaman \& Nguyen 2012), field management practices (irrigation type, geometry and application method of ammonium-based fertilisers) (Shepherd et al. 2012).

Statistically significant differences of contents of ammonium and nitrate nitrogen in soil were found between treatments without application of nitrogen fertilisers (control) and treatment fertilised, where nitrogen was applied via nitrogen-sulphur fertilisers (Table 7). Highly significant difference of content of nitrate nitrogen was determined at treatment fertilised with fertiliser DASA 26/13, where the total nitrogen dose was applied three times by split ap- plication, in comparison with fertiliser containing nitrification inhibitors ENSIN split application. Beltran-Rendon et al. (2011) reported nitrification inhibitors are compounds that effectively inhibit nitrification process when applied to soils in conjunction with ammonium fertilisers, such as urea or ammonium sulphate. Statistically non-significant differences of $\mathrm{N}_{-} \mathrm{NO}_{3}{ }^{-}$contents were found between split application of ENSIN and one-time application of fertilisers DASA 26/13 and ENSIN. Increase of nitrate nitrogen contents after split application of DASA 26/13 was not statistically significant, compared to treatments, where the total nitrogen dose of $140 \mathrm{~kg} / \mathrm{ha}$ was applied by one-time application via fertilisers DASA 26/13 and ENSIN. Statistically non-significant differences of ammonium nitrogen contents were found between DASA 26/13 and ENSIN, which were applied by split application and by one-time application during the winter barley growing season. The contents of ammonium and nitrate nitrogen were significantly affected by the ex-

$$
\mathrm{T} \text { a } \mathrm{b} 1 \mathrm{e} \quad 5
$$

Scheme of winter barley fertilisation treatments

\begin{tabular}{|c|c|c|c|c|c|c|c|}
\hline \multirow[t]{3}{*}{ Treatment } & \multirow[t]{3}{*}{ Fertiliser } & \multicolumn{2}{|c|}{$\begin{array}{c}\text { Regenerative } \\
\text { fertilisation BBCH } 25 \\
\text { April 4, 2016 and } \\
\text { March 17, } 2017 \\
\end{array}$} & \multicolumn{2}{|c|}{$\begin{array}{c}\text { Production fertilisation } \\
\text { BBCH } 32 \\
\text { May 2, } 2016 \text { and } \\
\text { March 29, } 2017 \\
\end{array}$} & \multicolumn{2}{|c|}{$\begin{array}{l}\text { Quality fertilisation } \\
\text { BBCH 49-51 } \\
\text { May 19, 2016 and } \\
\text { April 26, } 2017 \\
\end{array}$} \\
\hline & & \multicolumn{6}{|c|}{ Doses of nutrients $[\mathrm{kg} / \mathrm{ha}]$} \\
\hline & & $\mathrm{N}$ & $\mathrm{S}$ & $\mathrm{N}$ & $\mathrm{S}$ & $\mathrm{N}$ & $\mathrm{S}$ \\
\hline 1 & Control without fertilisation & - & - & - & - & - & - \\
\hline 2 & DASA 26/13 split application & 60 & 30 & 50 & 25 & 30 & 15 \\
\hline 3 & ENSIN split application & 60 & 30 & 50 & 25 & 30 & 15 \\
\hline 4 & DASA $26 / 13$ one-time application & 140 & 70 & - & - & - & - \\
\hline 5 & ENSIN one-time application & 140 & 70 & - & - & - & - \\
\hline
\end{tabular}

$\mathrm{T}$ a $\mathrm{b} 1$ e 6

Soil sampling dates during winter barley growing season

\begin{tabular}{|l|l|l|}
\hline Soil sampling & \multicolumn{2}{|c|}{ Soil sampling dates } \\
\hline $1^{\text {st }}$ sampling & \multicolumn{1}{|c|}{$2015 / 2016$} & March 29, 2017 (BBCH 32) \\
$2^{\text {nd }}$ sampling & May 2, 2016 (BBCH 32) & April 20, 2017 (BBCH 51) \\
$3^{\text {rd }}$ sampling & May 24, 2016(BBCH 51) & May 12, 2017 (BBCH 75) \\
$4^{\text {th }}$ sampling & June 10, 2016 (BBCH 83) & June 2, 2017 (BBCH 87) \\
\hline
\end{tabular}


perimental years. The content of available nitrogen forms $\left(\mathrm{N}-\mathrm{NH}_{4}^{+}\right.$and $\left.\mathrm{N}-\mathrm{NO}_{3}^{-}\right)$in the soil were significantly influenced by offtake of soil samples in soil depth of $0.0-0.3 \mathrm{~m}$ in both experimental years.

The lowest contents of nitrate $\left(\mathrm{N}-N O_{3}^{-}\right)$, ammonium $\left({\mathrm{N}-\mathrm{NH}_{4}}^{+}\right)$and mineral nitrogen $\left(\mathrm{N}_{\text {min }}\right)$ were observed at control treatment without application of nitrogen fertilisers in both experimental years. Relatively higher nitrate nitrogen contents in the soil were found after split application of DASA 26/13 and also after one-time application of DASA 26/13. On the contrary, the lowest values of nitrate nitrogen in soil were determined after application of ENSIN containing nitrification inhibitors, which was applied by split application and one-time application during the winter barley growing season. Similarly, Lam et al. (2015) state that, the nitrification inhibitor lowers nitrate leaching by preventing or slowing the microbial conversion of ammonium nitrogen to nitrate nitrogen in the soil.

The soil ammonium nitrogen contents ranged from 11.18 to $24.06 \mathrm{mg} / \mathrm{kg}$ in soil depth of $0.0-0.3 \mathrm{~m}$ and from 8.43 to $16.03 \mathrm{mg} / \mathrm{kg}$ in soil depth of 0.3-0.6 m (Table 8). The soil nitrate nitrogen contents ranged from 4.24 to $7.98 \mathrm{mg} / \mathrm{kg}$ in soil depth of $0.0-0.3 \mathrm{~m}$ and from 4.01 to $5.81 \mathrm{mg} / \mathrm{kg}$ in soil depth of $0.3-0.6 \mathrm{~m}$. One of the possible technologies to mitigating nitrogen losses such as nitrate leaching and $\mathrm{N}_{2} \mathrm{O}$ emissions is the application of nitrification inhibitors. Many nitrification inhibitors, such as dicyandiamide have been proven to be effective in reducing nitrification rates in soil (Gong et al. 2013). The presence of nitrification inhibitors in nitrogen-sulphur fertiliser ENSIN slowed down rate of nitrification process. Sivasakthy and Gnanavelrajah (2012) state that, the use of the nitrification inhibitors may retain nitrogen in the ammonium form that is less susceptible to leaching and thus minimizes nitrogen loss. Thus, the addition of inhibitors nitrification dicyandiamide and 1,2,4-triazole maintained soil nitrogen in ammonium form of nitrogen longer time. The lowest values of nitrate nitrogen were found after one-time application of ENSIN in both soil depths. The effect of dicyandiamide and 1,2,4-triazole was reflected at treatment fertilised with fertiliser ENSIN, and consequently the ammonium portion from the content of $\mathrm{N}_{\min }$ was increased by 7 relative $\%$ in soil depth of $0.0-0.3$ $\mathrm{m}$ and by 10 relative \% in soil depth of $0.3-0.6 \mathrm{~m}$ after one-time application of ENSIN, in comparison with treatments, where DASA 26/13 was applied by three times split application and also one-time appli-

$\mathrm{T}$ a b 1 e 7

Effect of addition of nitrification inhibitors on the content of available nitrogen forms in the soil in 2015-2017

\begin{tabular}{|c|c|c|}
\hline \multirow{2}{*}{ Treatment } & \multicolumn{2}{|c|}{ Content of $\mathrm{N}[\mathrm{mg} / \mathrm{kg}]$} \\
\hline & $\mathrm{N}-\mathrm{NH}_{4}^{+}$ & $\mathrm{N}-\mathrm{NO}_{3}^{-}$ \\
\hline Control & $5.87^{\mathrm{a}}$ & $4.13^{\mathrm{a}}$ \\
\hline DASA 26/13 split application & $17.96^{\mathrm{b}}$ & $6.95^{\mathrm{c}}$ \\
\hline ENSIN split application & $16.61^{\mathrm{b}}$ & $5.98^{\mathrm{b}}$ \\
\hline DASA $26 / 13$ one-time application & $15.01^{\mathrm{b}}$ & $6.75^{\mathrm{bc}}$ \\
\hline ENSIN one-time application & $16.32^{\mathrm{b}}$ & $6.50^{\mathrm{bc}}$ \\
\hline Experimental years & & \\
\hline Soil depth of $0.0-0.3 \mathrm{~m}$ & $18.21^{\mathrm{b}}$ & $6.52^{\mathrm{b}}$ \\
\hline Soil depth of $0.3-0.6 \mathrm{~m}$ & $10.49^{\mathrm{a}}$ & $5.60^{\mathrm{a}}$ \\
\hline$L S D_{0.05}$ treatment & 4.36 & 0.79 \\
\hline$L S D_{0.05}$ year & 2.76 & 0.50 \\
\hline$L S D_{0.05}$ soil depth & 2.76 & 0.50 \\
\hline
\end{tabular}

where: $L S D_{0.05}$ - least significant difference at the level $\alpha=0.05$ (LSD test); different letter behind a numerical value indicate statistically significant difference at the level $95.0 \%$ 
cation. Simultaneously, the lowest nitrate nitrogen portion was determined after one-time application of ENSIN. The portion of $\mathrm{N}^{-\mathrm{NO}_{3}}{ }^{-}$was reduced by 32 relative \% in soil depth of $0.0-0.3 \mathrm{~m}$ and by 36 relative $\%$ in soil depth of $0.3-0.6 \mathrm{~m}$, compared to DASA 26/13, which was applied by split application and by one-time application. In other study, Panáková et al. (2016) determined that in the experimental year 2013, the soil nitrate nitrogen content under maize growing was decreased by 9 relative $\%$ and the soil ammonium nitrogen content was increased by 18 relative $\%$ at treatment, where ENSIN was applied by one-time application, in comparison with treatments, where fertilisers LAD 27 and DASA 26/13 without inhibitors of nitrification were applied.

In experimental years 2016/2017, the contents of mineral nitrogen ranged from 7.10 to $30.40 \mathrm{mg} / \mathrm{kg}$ in soil depth of $0.0-0.3 \mathrm{~m}$ and from 6.30 to $21.10 \mathrm{mg} / \mathrm{kg}$

T a b 1 e 8

Content of ammonium and nitrate nitrogen and portion of nitrogen forms from $\mathrm{N}_{\min }$ in the soil in $2015-2016$ (average of sampling dates and replications)

\begin{tabular}{|c|c|c|c|c|c|c|}
\hline \multirow[t]{2}{*}{ Nutrition treatment } & \multirow{2}{*}{$\begin{array}{l}\text { Soil depth } \\
{[\mathrm{m}]}\end{array}$} & \multicolumn{2}{|c|}{$\begin{array}{c}\text { Content of N } \\
{[\mathrm{mg} / \mathrm{kg}]}\end{array}$} & \multirow{2}{*}{$\underset{[\mathrm{mg} / \mathrm{kg}]}{\mathrm{N}_{\min }}$} & \multicolumn{2}{|c|}{$\begin{array}{c}\text { Portion of } \mathrm{N} \text { from } \mathrm{N}_{\min } \text { in the } \\
\text { soil [\%] }\end{array}$} \\
\hline & & $\mathrm{N}-\mathrm{NH}_{4}^{+}$ & $\mathrm{N}^{-\mathrm{NO}_{3}-}$ & & $\mathrm{N}-\mathrm{NH}_{4}^{+}$ & $\mathrm{N}^{-\mathrm{NO}_{3}}{ }_{3}^{-}$ \\
\hline \multirow{2}{*}{ Control } & $0.0-0.3$ & 11.18 & 4.24 & 15.42 & 72 & 28 \\
\hline & $0.3-0.6$ & 8.43 & 4.01 & 12.44 & 68 & 32 \\
\hline \multirow{2}{*}{$\begin{array}{l}\text { DASA 26/13 } \\
\text { split application }\end{array}$} & $0.0-0.3$ & 24.06 & 7.98 & 32.04 & 75 & 25 \\
\hline & $0.3-0.6$ & 13.43 & 5.81 & 19.24 & 70 & 30 \\
\hline \multirow{2}{*}{$\begin{array}{l}\text { ENSIN } \\
\text { split application }\end{array}$} & $0.0-0.3$ & 23.30 & 6.54 & 29.84 & 78 & 22 \\
\hline & $0.3-0.6$ & 16.03 & 5.49 & 21.52 & 74 & 26 \\
\hline \multirow{2}{*}{$\begin{array}{l}\text { DASA } 26 / 13 \\
\text { one-time application }\end{array}$} & $0.0-0.3$ & 19.35 & 6.50 & 25.85 & 75 & 25 \\
\hline & $0.3-0.6$ & 11.73 & 4.91 & 16.64 & 70 & 30 \\
\hline \multirow{2}{*}{$\begin{array}{l}\text { ENSIN } \\
\text { one-time application }\end{array}$} & $0.0-0.3$ & 19.95 & 4.69 & 24.64 & 81 & 19 \\
\hline & $0.3-0.6$ & 15.43 & 4.29 & 19.72 & 78 & 22 \\
\hline
\end{tabular}

T a b 1 e 9

Content of ammonium and nitrate nitrogen and portion of nitrogen forms from $\mathrm{N}_{\min }$ in the soil in $2016-2017$ (average of sampling dates and replications)

\begin{tabular}{|c|c|c|c|c|c|c|}
\hline \multirow{2}{*}{ Nutrition treatment } & \multirow{2}{*}{$\begin{array}{l}\text { Soil depth } \\
{[\mathrm{m}]}\end{array}$} & \multicolumn{2}{|c|}{$\begin{array}{c}\text { Content of } \mathrm{N} \\
{[\mathrm{mg} / \mathrm{kg}]}\end{array}$} & \multirow{2}{*}{$\underset{[\mathrm{mg} / \mathrm{kg}]}{\mathrm{N}_{\min }}$} & \multicolumn{2}{|c|}{$\begin{array}{c}\text { Portion of } \mathrm{N} \text { from } \mathrm{N}_{\min } \text { in the } \\
\text { soil }[\%]\end{array}$} \\
\hline & & $\mathrm{N}-\mathrm{NH}_{4}^{+}$ & $\mathrm{N}-\mathrm{NO}_{3}^{-}$ & & $\mathrm{N}-\mathrm{NH}_{4}^{+}$ & $\mathrm{N}-\mathrm{NO}_{3}^{-}$ \\
\hline \multirow{2}{*}{ Control } & $0.0-0.3$ & 2.30 & 4.80 & 7.10 & 32 & 68 \\
\hline & $0.3-0.6$ & 2.00 & 4.30 & 6.30 & 32 & 68 \\
\hline \multirow{2}{*}{$\begin{array}{l}\text { DASA } 26 / 13 \\
\text { split application }\end{array}$} & $0.0-0.3$ & 17.80 & 7.20 & 25.00 & 71 & 29 \\
\hline & $0.3-0.6$ & 10.30 & 5.90 & 16.20 & 64 & 36 \\
\hline \multirow{2}{*}{$\begin{array}{l}\text { ENSIN } \\
\text { split application }\end{array}$} & $0.0-0.3$ & 23.90 & 6.50 & 30.40 & 79 & 21 \\
\hline & $0.3-0.6$ & 7.20 & 5.30 & 12.50 & 58 & 42 \\
\hline \multirow{2}{*}{$\begin{array}{l}\text { DASA } 26 / 13 \\
\text { one-time application }\end{array}$} & $0.0-0.3$ & 15.30 & 8.00 & 23.30 & 66 & 34 \\
\hline & $0.3-0.6$ & 13.00 & 8.10 & 21.10 & 62 & 38 \\
\hline \multirow{2}{*}{$\begin{array}{l}\text { ENSIN } \\
\text { one-time application }\end{array}$} & $0.0-0.3$ & 16.20 & 7.80 & 24.00 & 68 & 32 \\
\hline & $0.3-0.6$ & 9.10 & 8.30 & 17.40 & 52 & 48 \\
\hline
\end{tabular}


in soil depth of $0.3-0.6 \mathrm{~m}$ (Table 9). The highest values of $\mathrm{N}^{-\mathrm{NH}_{4}^{+}}$, as well as contents of $\mathrm{N}_{\text {min }}$ were determined at treatments fertilised with ENSIN, where the total nitrogen dose was applied by three times split application. Nitrification inhibitors dicyandiamide and 1,2,4-triazole which forms part of nitrogen-sulphur fertiliser ENSIN had positive effect on decrease of nitrate nitrogen concentration in the soil. The lowest contents of nitrate nitrogen were found after split application of ENSIN in both soil depths. Inhibitors of nitrification dicyandiamide and 1,2,4-triazole limited the nitrification process in the soil. The lowest nitrate nitrogen portion from the content of $\mathrm{N}_{\min }$ was determined after three time split application of ENSIN. This resulted in a decrease of soil nitrate nitrogen concentration by 38 relative $\%$ in soil depth of $0.0-0.3 \mathrm{~m}$, compared to DASA $26 / 13$, which applied split and by 62 relative $\%$ in soil depth of $0.3-0.6 \mathrm{~m}$, in comparison with treatment fertilised, where the total nitrogen of $140 \mathrm{~kg} / \mathrm{ha}$ was applied by one-time application of fertiliser DASA 26/13. Split application of ENSIN increased portion of ammonium nitrogen from content of $\mathrm{N}_{\min }$ by 10 relative $\%$ in soil depth of $0.0-0.3 \mathrm{~m}$, in comparison with treatment fertilised with DASA 26/13 without nitrification inhibitors, where was applied by split application and by 16 relative $\%$ in soil depth of $0.0-0.3 \mathrm{~m}$, compared to treatment fertilised with DASA 26/13, which was applied by one-time application during regenerative fertilisation. However, in soil depth of $0.3-0.6 \mathrm{~m}$, split application of ENSIN decreased portion of $\mathrm{N}^{-\mathrm{NH}_{4}+}$ by 10 relative $\%$ and increased portion $\mathrm{N}^{-\mathrm{NO}_{3}}{ }^{-}$by 14 relative $\%$, in comparison with split application of DASA 26/13. Also, split application of fertiliser ENSIN decreased portion of $\mathrm{N}^{-\mathrm{NH}_{4}+}$ by 7 relative $\%$ and increased portion $\mathrm{N}_{-} \mathrm{NO}_{3}^{-}$by 10 relative $\%$, compared to onetime application of DASA 26/13. Panáková et al. (2016) published that on the average of four experimental years and three soil depths of the soil profile, one-time application of fertiliser ENSIN containing nitrification inhibitors substantially reduced portion of nitrate nitrogen from the content of mineral nitrogen in soil by $7-32$ relative $\%$ during maize growing season. Liu et al. (2013) observed that the application of DCD and DMPP slightly decreased the soil $\mathrm{N}_{-} \mathrm{NO}_{3}{ }_{3}^{-}$contents and significantly increased the soil $\mathrm{N}-\mathrm{NH}_{4}^{+}$contents. The conversion processes between $\mathrm{N}_{-} \mathrm{NH}_{4}^{+}$and $\mathrm{N}-\mathrm{NO}_{3}{ }^{-}$(nitrification and denitrification) were inhibited by the nitrification inhibitors. Slamka and Ložek (2015) determined that, the presence of nitrification inhibitors in fertiliser ENSIN had been positive effect on slowing down of conversion ammonium nitrogen to nitrate nitrogen during oilseed rape growing season. One-time application of ENSIN substantially reduced $\mathrm{N}_{-} \mathrm{NO}_{3}^{-}$ portion from content of mineral nitrogen by 14 relative $\%$ in soil depth of $0.0-0.3 \mathrm{~m}$ and by 20 relative $\%$ in soil depth of $0.3-0.6 \mathrm{~m}$. Qiao et al. (2015) determined that, on average, nitrification inhibitor reduced nitrate leaching $(-47 \%,-59 \%$ to $-32 \%)$. The reduction in nitrate leaching was significant for different types of ecosystem, fertiliser and soil texture. For ammonium leaching, the overall effect of nitri-

$\mathrm{T}$ a $\mathrm{b} 1 \mathrm{e} 10$

Effect of applied fertilisers on the grain yield of winter barley

\begin{tabular}{|l|c|c|}
\hline \multirow{2}{*}{ Nutrition treatment } & \multicolumn{2}{|c|}{ Grain yield [t/ha] } \\
\cline { 2 - 3 } & $2015 / 2016$ & $2016 / 2017$ \\
\hline Control & $4.44^{\mathrm{a}}$ & $4.58^{\mathrm{a}}$ \\
DASA 26/13split application & $7.25^{\mathrm{cd}}$ & $8.69^{\mathrm{bcd}}$ \\
ENSIN split application & $5.15^{\mathrm{b}}$ & $8.70^{\mathrm{cd}}$ \\
DASA 26/13 one-time application & $6.68^{\mathrm{c}}$ & $8.33^{\mathrm{b}}$ \\
ENSIN one-time application & $7.85^{\mathrm{d}}$ & $8.85^{\mathrm{d}}$ \\
$L S D_{0.05}$ & 0.71 & 0.37 \\
\hline
\end{tabular}

where: $L S D_{0.05}$ - least significant difference at the level $\alpha=0.05$ ( $L S D$ test); different letter behind a numerical value indicate statistically significant difference at the level $95.0 \%$ 
fication inhibitors was not significant. The reduction in soil nitrate concentration under nitrification inhibitor addition resulted in a significant reduction in nitrate leaching. Although soil ammonium concentration increased under nitrification inhibitor application, ammonium leaching was not changed, probable because ammonium nitrogen is not as mobile as nitrate nitrogen. Overall, nitrification inhibitor application reduced total nitrogen loss by $16.5 \%$, suggesting that nitrification inhibitor application is an effective practice to reduce nitrogen lost to environment. Gong et al. (2013) found out that, without DCD addition, soil content of ammonium nitrogen in treatment $\mathrm{N}$ declined sharply and was significantly lower than that in treatments N+DCD 1 and N+DCD 2 at day 7 and until the end of the experiment. Comparison with treatment N+DCD 1, a double dose of DCD maintained significantly higher levels of soil ammonium nitrogen from day 14 to the end of the experiment. In other research, Sivasakthy and Gnanavelrajah (2012) also determined that nitrate leaching from nitrification inhibitors treated pots were significantly less than relevant untreated pots. Significant reduction in nitrate leaching loss was observed between soil treatments with and without nitrification inhibitors. However, it should be aware that many factors, such as climate, soil types, cropping time, seasonality fertilisation and fertilisation method, would affect the value of nitrogen loss factor and eventually alter the estimation for the amount of nitrogen loss (Qiao et al. 2015).

The grain yields of winter barley are stated in Table 10. It can be seen from the table that presence of nitrification inhibitors in fertiliser ENSIN showed positive effect on grain yield because in the both experimental years the highest yield ( $7.85 \mathrm{t} / \mathrm{ha}$ and $8.85 \mathrm{t} / \mathrm{ha}$, respectively) was achieved just in the treatment where ENSIN was applied in one-time. On the other side, split application of fertiliser ENSIN was not successful in the first experimental year (5.15 t/ha), but very effective in the second year of experiment $(8.70 \mathrm{t} / \mathrm{ha})$.

\section{CONCLUSIONS}

The presence of nitrification inhibitors in nitrogen-sulphur fertiliser ENSIN had positive effect on reduction of nitrate nitrogen concentration in soil. The common effect of dicyandiamide and 1,2,4-triazole was confirmed at treatments fertilised with fertiliser ENSIN, which was applied by one-time application or by split application during the winter barley growing season. The inhibitors retained soil nitrogen in the ammonium form $\left(\mathrm{N}^{-\mathrm{NH}_{4}}{ }^{+}\right)$longer time. The application of ENSIN decreased the portion of nitrate nitrogen from the content of mineral nitrogen in soil by 14-62 relative \% in comparison with fertiliser DASA 26/13, which was applied by split application and one-time application. The one-time application of ENSIN was more effective in experimental year 2015/2016. Oppositely, in the experimental year 2016/2017, split application of ENSIN was more effective in reducing nitrate nitrogen portion from content of mineral nitrogen in soil. This different effect of nitrification inhibitors in ENSIN was caused by various weather conditions in respective experimental years.

The nitrification inhibitors contributed to gradual releasing of ammonium nitrogen what caused higher concentrations of ammonium nitrogen compared to nitrate nitrogen in soil. The reduction of soil $\mathrm{N}^{-\mathrm{NO}_{3}}{ }^{-}$ concentration subsequently resulted in a considerably decrease of $\mathrm{N}^{-\mathrm{NO}_{3}}{ }^{-}$leaching. The portion of ammonium nitrogen from the content of $\mathrm{N}_{\text {min }}$ in soil was increased by 3-16 relative \% in comparison with fertiliser DASA 26/13, which was applied by split application and one-time application.

Acknowledgements. This work was co-funded by European Community under project no 26220220180: Building Research Centre „AgroBioTech".

\section{REFERENCES}

AKIYAMA, H. - YAN, X. - YAGI, K. 2010. Evaluation of effectiveness of enhanced-efficiency fertilizers as mitigation options for $\mathrm{N}_{2} \mathrm{O}$ and $\mathrm{NO}$ emissions from agricultural soils: meta-analysis. In Global Change Biology, vol. 16, pp. 1837-1846.

BARTH, G. - von TUCHER, S. - SCHMIDHALTER, U. 2001. Influence of soil parameters on the effect of 3,4-dimethylpyrazole-phosphate as a nitrification inhibitor. In Biology and Fertility of Soils, vol. 34, no. 2, pp. 98-102.

BARTH, G. - von TUCHER, S. - SCHMIDHALTER, U. 2008. Effectiveness of 3,4-dimethylpyrazole phosphate as nitrification inhibitor in soil as influenced by inhibitor concentration, application form, and soil matric potential. In Pedo- 
sphere, vol. 18 , no. 3, pp. 378-385.

BELTRAN-RENDON, D. - RICO-FRAGOZO, D. FARFAN-CACERES, L. - RESTREPO-DIAZ, H. HOYOS-CARVAJAL, L. 2011. The effect of nitrification inhibitor 3,4-dimethylpyrazole phosphate (DMPP) on nitrifying organism populations under in vitro conditions. In Agricultural Sciences, vol. 2, no. 3, pp. 198-200.

DI, H.J. - CAMERON, K.C. 2002. Nitrate leaching in temperate agroecosystems: sources, factors and mitigating strategies. In Nutrient Cycling in Agroecosystems, vol. 46, pp. 237-256.

DI, H.J. - CAMERON, K.C. 2005. Reducing environmental impacts of agriculture by using a fine particle suspension nitrification inhibitors to decrease nitrate leaching from gazed pastures. In Agriculture, Ecosystems and Environment, vol. 109 , no. 3-4, pp. 202-212.

ELBL, J. - VAVERKOVÁ, M.D. - ADAMCOVÁ, D. PLOŠEK, L. - KINTL, A. - LOŠÁK, T. - HYNŠT, J. KOTOVICOVÁ, J. 2014. Influence of fertilization on microbial activities, soil hydrophobicity and mineral nitrogen leaching. In Ecological Chemistry and Engineering $S$, vol. 21, no. 4, pp. 661-675. DOI: https://doi.org/10.1515/ eces-2014-0048

FIALA, K. 1999. Binding methods for soil analysis. Partial monitoring system- Soil. Bratislava : VUPOP, 142 p. ISBN 80-85361-55-8

FERNANDEZ-ESCOBAR, R. - GARCÍA-NOVELO, J.M. RESTREPO-DÍAZ, H. 2011. Mobilization of nitrogen in the olive bearing shoots after foliar application of urea. In Scientia Horticulturae, vol. 127, pp. 452-454.

GIMÉNEZ, C. - DIAZ, E. - ROSADO, F. - GARCIA-FERRER, A. - SANCHEZ, M. - PARRA, M. - DÍAZ, M. - PE, F. 2001. Characterization of current management practices with high risk of nitrate contamination in agricultural areas of southern Spain. In Acta Horticulturae, vol. 563, pp. $73-80$.

GONG, P. - ZHANG, L. - WU, Z. - SHANG, Z. - LI, D. 2013. Does the nitrification inhibitor dicyandiamide affect the abundance of ammonia-oxidizing bacteria and archaea in Hap-Udic Luvisol? In Journal of Soil Science and Plant Nutrition, vol. 13, no. 1, pp. 35-42.

HUBER, D. - WARREN, H. - NELSON, D. - TSAI, C. 1977. Nitrification inhibitors: new tools for food production. In BioSience, vol. 27, no. 8, pp. 523-529.

CHEN, Y.X. - ZHANG, Y. - LIU, H.Y. 2003. Reduction of nitrate from groundwater: powder catalysts and catalytic membrane. In Journal of Environmental Sciences, vol. 15, no. 5 , pp. $600-606$.

IGNACIO, I. - MURO, J. - AZPILIKUETA, M. et al. 2003. Ammonium oxidation kinetics in the presence of nitrificatopn inhibitor DCD and DMPP at various temperature. In Australian Journal of Soil Research, vol. 41, no. 6, pp. $1177-1183$

IRIGOYEN, I. - MURO, J. - AZPILIKUETA, M. - APARICIO-TEJO, P. - LAMSFUS, C. 2003. Ammonium oxidation kinetics in the presence of nitrification inhibitors DCD and DMPP at various temperatures. In Australian Journal of Soil Research, vol. 41, pp. 1177-1183.

KOŽNÁROVÁ, V. - KLABZUBA, J. 2002. Recommendation of World Meteorological Organization to describing meteorological or climatological conditions. In Plant Production, vol. 48, no. 4, pp. 190-192.

KNOBELOCH, L. - SALNA, B. - HOGAN, A. et al. 2000. Blue babies and nitrate-contaminated well water. In Journal Environmenal Health Perspectives, vol. 108, no. 7, pp. 675-678.

KOVÁČIK, P. 1997. Soil, plant, fertilizer analysis and nutrient dose calculation for field and horticultural crops. Nitra : SPU, 99p. ISBN 80-7137-355-9

LAM, S.K. - SUTER, H. - DAVIES, R. - BAI, M. - SUN, J. - CHEN, D. 2015. Measurement and mitigation of nitrous oxide emissions from a high nitrogen input vegetable system. In Scientific Reports, vol. 5, no. 8208, pp. 1-4.

LI, H. - LIANG, X. - CHEN, Y. - LIAN, Y. - TIAN, G. - NI, W. 2008. Effect of nitrification inhibitor DMPP on nitrogen leaching, nitrifiyng organism, and enzyme activities in a rice-oilseed rape system. In Journal of Environment Sciences, vol. 20, pp. 149-155. DOI:10.1016/S1001-0742(08)6002

LIU, G.D. - WU, W.L. - ZHANG, J. 2005. Regional differentiation of non-point source pollution of agriculture-derived nitrate nitrogen in groundwater in northern China. In $\mathrm{Ag}$ riculture, Ecosystems and Environment, vol. 107, no. 2-3, pp. 211-220.

LIU, C. - WANG, K. - ZHENG, X. 2013. Effects of nitrification inhibitors (DCD and DMPP) on nitrous oxide emission, crop yield and nitrogen uptake in a wheat-maize cropping system. In Biogeosciences, vol. 10, p. 2427-2437.

MARSCHNER, H. 1995. Mineral nutrition of higher plants. London : Academic Press Limited, 889 p.

MEHLICH, A. 1984. Mehlich 3 soil test extractant: A modification of Mehlich 2 extractant. In Communications in Soil Science and Plant Analysis Science, vol. 15, no. 22, pp. 1409-1416.

MENÉNDEZ, S. - BARRENA, I. - SETIEN, I. - GONZÁLEZMURUA, C. - ESTAVILLO, J.M. 2012. Efficiency of nitrification inhibitor DMPP to reduce nitrous oxide emissions under different temperature and moisture conditions. In Soil Biology and Biochemistry, vol. 53, pp. 82-89.

MORALES, S.E. - JHA, N. - SAGGAR, S. 2015. Impact of urine and the application of the nitrification inhibitor DCD on microbial communities in dairy-grazed pasture soils. In Soil Biology and Biochemistry, vol. 88, pp. 344-353.

MUSILOVÁ, L. - LOŠÁK, T. - HLUŠEK, J. - VÍTĚZOVÁ, M. - JŮZL, M. - ELZNER, P. - FILIPČ́́K, R. - JŮZL, M. - von BENNEWITZ ÁLVAREZ, E.A. 2012. The effect of urea and urea with urease inhibitor on the content of macronutrients in tubers and tops of potatoes (Solanum tuberosum L.). In Acta Universitatis Agriculturae et Silviculturae Mendelianae Brunensis, vol. 60, no. 5, pp. 167-172.

O'CONNOR, P.J. - HENNESSY, D. - BROPHY, C. O'DONOVAN, M. - LYNCH, M.B. 2012. The effect of nitrification inhibitor dicyandiamide (DCD) on herbage production when applied at different times and rates in the autumn and winter. In Agriculture, Ecosystems and Environment, vol. 152, pp. 79-89.

OECD. 2003. Cyanoguanidine. SIDS initial assessment report. Arona, Italy : UNEP Publications, $75 \mathrm{p}$.

PANÁKOVÁ, Z. - SLAMKA, P. - LOŽEK, O. 2016. Effect of nitrification inhibitors on the content of available nitrogen forms in the soil under maize (Zea mays, L.) growing. In Journal of Central European Agriculture, vol. 17, no. 4, pp. 1013-1032.

PLOŠEK, L. - ELBL, J. - LOŠÁK, T. - KUŽEL, S. - KINTL, A. - JUŘIČKA, D. - KYNICKÝ, J. - MARTENSSON, A. - BRTNICKÝ, M. 2017. Leaching of mineral nitrogen in the soil influenced by addition of compost and $\mathrm{N}$-mineral fertilizer. In Acta Agriculturae Scandinavica Section B: Soil and Plant Science, vol. 67, no. 7, p. 607-614.

QIAO, CH. - LIU, L. - HU, S. - COMPTON, J.E. - GREAVER, T.L. - LI, Q. 2015. How inhibiting nitrification affects nitrogen cycle and reduces environmental impacts of anthropogenic nitrogen input. In Global Change Biology, vol. 21 , pp. 1249-1257.

SANCHEZ, E.E. - KHEMIRA, H. - RIGHETTI, T. 1995. Nit- 
rogen management in orchards. In BACON, P.E. (Ed.) Nitrogen fertilization in the environment. New York : Marcel Dekker Inc, pp. 327-380.

SHEPHERD, M. - WYATT, J. - WELTEN, B. 2012. Effect of soil type and rainfall on dicyandiamide concentrations in drainage from lysimeters. In Soil Research, vol. 50, pp. $67-75$.

SIVASAKTHY, K. - GNANAVELRAJAH, N. 2012. Organic nitrogen sources and nitrification inhibitors on leaching and phyto-accumulation of nitrate and yield of Amaranthus polygamous. In World Journal of Agricultural Sciences, vol. 8 , no. 2 , pp. $208-211$

SLAMKA, P. - LOŽEK, O. 2015. Effect of ENSIN fertilizer on the seed yield of oil rape (Brassica napus L.) and content of nitrates in soil. In Agrochémia, vol. 19, no. 55, pp. 12-18.

ŤURIN, I.V. 1966. K metodike analiza deja sravnítel'nogo izučenja sostava počvennogo peregnoja ili gumusa. In Voprosy Genezisa i Plodorodija Počv, Moskva : Nauka.

VERMA, A. - TYAGI, L. - SINGH, S.N. 2008. Attenuation of $\mathrm{N}_{2} \mathrm{O}$ emission rates from agricultural soil at different di- cyandiamide concentrations. In Environmental Monitoring and Assessment, vol. 137, pp. 287-293.

ZAMAN, M. - NGUYEN, M.L. 2012. How application timings of urease and nitrification inhibitors affect $\mathrm{N}$ losses from urine patches in pastoral system. In Agriculture, Ecosystems and Environment, vol. 156, pp. 37-48.

ZERULLA, W. - BARTH, T. - DRESSEL, J. - ERHARDT, K. - VON LOCQUENGHIEN, K.H. - PASDA, G. - RÄDLE, M. - WISSEMEIER, A. 2001. 3,4-dimethylpyrazole phosphate (DMPP) - a new nitrification inhibitor for agriculture and horticulture. In Biology and Fertility of Soils, vol. 34 , no. 2 , pp. $79-84$

ZHANG, M. - FAN, CH. - LI, Q.L. - LI, B. - ZHU, Y.Y. XIONG, Z.Q. 2015. A 2-yr field assessment of the effects of chemical and biological nitrification inhibitors on nitrous oxide emissions and nitrogen use efficiency in an intensively managed vegetable cropping system. In Agriculture, Ecosystems and Environment, vol. 201, pp. 43-50.

Received: February 5, 2018 